УДК 328.185:342.95

\author{
N. Datsii, \\ Doctor of Sciences in Public Administration, Professor, Professor \\ of the Department of economic theory, intellectual property \\ and public administration, Zbytomyr National Agroecological University \\ ORCID ID: 0000-0003-0640-6426 \\ S. Hubert, \\ Master of specialty "Public management and administration" of the department \\ of economic theory, intellectual property and public administration, \\ Zbytomyr National Agroecological University \\ ORCID ID: 0000-0002-6368-1902 \\ L. Kbarchenko, \\ Master of specialty "Public management and administration " of the department \\ of economic theory, intellectual property and public administration, \\ Zhytomyr National Agroecological University \\ ORCID ID: 0000-0002-1526-8224
}

DOI: $10.32702 / 2306-6814.2020 .15-16.121$

\title{
ANTI-CORRUPTION POLICY AS A NECESSARY CONDITION FOR THE IMPROVEMENT OF THE QUALITY OF LIFE IN CIVIL SOCIETY
}

\author{
Н. В. Аацій, \\ А. держ. упр., професор, професор кафедри економічної теорії, інтелектуальної власності \\ та публічного управління, Житомирський національний агроекологічний університет \\ C. А. Губерт, \\ магістр спеціальності "Публічне управління та адміністрування" кафедри економічної теорії, інтелектуальної \\ власності та публічного управління, Житомирський національний агроекологічний університет \\ А. С. Харченко, \\ магістр спеціальності "Публічне управління та адміністрування" кафедри економічної теорії, інтелектуальної \\ власності та публічного управління, Житомирський національний агроекологічний університет
}

\section{АНТИКОРУПЦІЙНА ПОАІТИКА ЯК НЕОБХІАНА УМОВА ПІАВИЩЕННЯ ЯКОСТІ ЖИТТЯ У ГРОМААЯНСЬКОМУ СУСПІАЬСТВІ}

Groups of legal factors of the existence and reproduction of corruption in the civil society and in the current domestic legislation are defined.

It is proved that the main task should not be the drafting of new rules of the conduct, which have already been enshrined in law more than once ("code of ethics", "code of conduct", "code of morality") and should serve as a benchmark for the implementation not only by officials but also by any ordinary citizen, but a detailed development of the mechanisms for their use. Only under the latter condition the codes of ethics and morals will be able to become an effective means of preventing corruption and a condition for increasing trust in the authorities.

The question of the need for scientific development of the remuneration system for civil servants of different categories depending on the complexity of the work, the qualifications of the employee, the effectiveness of his professional (official) activities, is considered. They point out that the wages symbolize the evaluation of the work in the field of management, which affects the prestige of the profession and the distribution of the labor resources. In this case, it is fair to ask what salary requirements should apply at present for the public servants.

It is substantiated that among the organizational and managerial reasons for the existence of corruption in the context of the continuous reform of public authorities and local self-government in modern society, the instability of the civil service in these bodies should be included.

It is proved that the inefficiency of law enforcement agencies in stopping and preventing corruption is caused by the "leaching" of experienced and honest personnel from the law enforcement system 
in the last decade. All this ultimately leads to a greater public danger and the prevalence of both the very manifestations of corruption and its negative social consequences.

It is substantiated that the socio-psychological factor of corruption is the perception of society, its political institutions and government agencies to "acquire" votes by providing inexpensive gifts, promises of quick material enrichment or a "bright future" by candidates for the elected government positions in government and local self-government as a normal political phenomenon.

It is proved that another ideological factor of the existence of corruption may be the lack of political and legal culture of the majority of Ukrainians, which is reflected primarily in the process of elections to representative and legislative bodies of state and local government, when voters vote for those who offered small money amounts or tangible assets.

Визначено групи правових чинників існування і відтворення корупції в громадянському суспільстві та в чинному вітчизняному законодавстві.

Доведено, що основним завданням має стати не складання нових правил поведінки, які вже закріплювалися нормативно не раз ("етичний кодекс", "кодекс правила поведінки службовців", "кодекс моралі") і мають бути еталоном для виконання не лише чиновницьким апаратом, але й будь-яким пересічним громадянином, а детальна розробка механізмів їх використання. Лише за останньої умови кодекси норм етики і моралі зможуть стати дієвим засобом запобігання корупції та умовою підвищення довіри до органів влади.

Розглянуто питання про необхідність наукової розробки системи оплати праці для публічних службовців різних категорій залежно від складності роботи, кваліфікації працівника, ефективності його професійної (службової) діяльності. Вони вказують, що заробітна плата символізує оцінку праці в сфері управлінської діяльності, яка впливає на рівень престижу професії та розподіл трудових ресурсів. У такому випадку справедливо поставити питання про те, які вимоги до заробітної плати публічних службовців повинні застосовуватися на даний час.

Обгрунтовано, що до числа організаційно-управлінських причин існування корупції в умовах безперервного реформування органів державної влади і місцевого самоврядування в сучасному суспільстві слід віднести і нестабільність державної служби в цих органах.

Доведено, що неефективність діяльності правоохоронних органів у припиненні і запобіганні корупцією викликана "вимиванням" в останнє десятиліття досвідчених і чесних кадрів з правоохоронної системи. Все це призводить, в кінцевому підсумку, до більшої суспільної небезпеки і поширеності, як самих проявів корупції, так і її негативних соціальних наслідків.

Обгрунтовано, що соціально-психологічним фактором існування корупції є сприйняття суспільством, його політичними інститутами і державними органами "придбання"голосів виборців шляхом надання недорогих подарунків, обіцянок швидкого матеріального збагачення або "світлого майбутнього" з боку кандидатів на виборні вищі державні посади в органи влади i місцевого самоврядування як нормального політичного явища.

Доведено, що іншим ідеологічним фактором існування корупції може виступати не сформованість політичної і правової культури більшості українців, що відбивається передусім на процесі виборів до представницьких і законодавчих органів державної влади і місцевого самоврядування, коли виборці голосують на виборах за осіб, які запропонували невеликі грошові суми або матеріальні цінності.

Key words: anti-corruption policy, civil society, determinants of the corruption, corruption-generating principle, public service, public system reform, social factor, quality of life.

Ключові слова: антикорупційна політика, громадянське суспільство, детермінанти корупції, корупційногений принцип, публічна служба, реформуВання публічної системи, соціальний фрактор, якість життя.

\section{THE PURPOSE OF THE ARTICLE}

The purpose of the article is to identify the main determinants of the development of public corruption in the period of systemic reforms; to study the factors of the existence and reproduction of corruption in society; develop proposals for improving anti-corruption policy as a necessary condition for improving the quality of life in civil society.

\section{FORMULATION OF THE PROBLEM}

Unfortunately, from the general discussion of the problem of corruption with the constant statement of the damage caused by it and many other things that accompany it, society during this time, in fact, has made little progress in the real fight against its manifestations. Moreover, experts and the population unanimously note that without proper counteraction, corruption is rapidly gaining 
strength and is increasingly becoming an independent and very important social and political factor, having a devastating effect on the further development of the state. In this regard, it seems necessary to address some theoretical and methodological issues of analysis of corruption, as well as a number of more general issues that are important to keep in mind when studying this complex phenomenon of social life.

\section{ANALYSIS OF RECENT RESEARCH AND PUBLICATIONS}

Problems of formation and implementation of anticorruption policy in the public service of Ukraine, implementation of anti-corruption measures, development of anti-corruption legislation were studied by such scientists as: Y. Bytyak, E. Dodin, D. Zabroda, V. Kivalov, S. Maksymov, I. Matskevych, M Melnyk, V. Solovyov and others. Analysis of the state and degree of scientific developments in foreign and domestic sources on the researched issues shows that the issue of preventing and combating corruption is of great interest to scientists, politicians and managers.

\section{PRESENTATION OF THE MAIN MATERIAL}

Considering corruption as a negative socio-legal phenomenon, a natural question arises: why is it happening? What are the causes that generate, transform and preserve this specific negative phenomenon in modern society, and, accordingly, how is it possible to overcome it?

At first glance, the question of the causes of crime in general and the causes of corruption in particular may seem quite simple. At the same time, the causes of crime as a general phenomenon and the causes of corruption as a private one are slightly different, although they are based on a common beginning - contempt for existing criminal law regulations.

According to domestic researchers [2], the factors that determine crime, including corruption, in terms of content or areas of social life include: 1) legal; 2) organizational and managerial; 3) educational; 4) ideological; 5) socio-economic; 6) moral and psychological; 7) other causes and conditions, or processes and phenomena that cause (determine) crime in these areas.

Experts [3] divide the main legal factors that determine corruption in modern society into several independent, but interconnected and interdependent groups.

The first group of legal factors that determine corruption, experts include improper legal regulation of state and public activities. Among these most often domestic experts are:

- improper legal regulation of official powers of officials of public authorities and local self-government;

- lack of clear division of competence between them;

- duplication and combination of official duties of officials of different departments.

Scholars [7, p.18] point to the need for more detailed regulation of the activities of members of election commissions, as well as other participants in the election process. In their view, improper regulation of the activities of election commission members and other participants in election processes can lead to the commission of electoral offenses, including in the form of electoral corruption.
Another group of legal factors for the existence and reproduction of corruption in society include shortcomings in current domestic legislation that are not eliminated for a long time.

According to some scientists [1, p. 150; 8, p. 225], the legal reason for the existence of corruption in modern society is the lack of effectiveness of current domestic criminal law on liability for specific forms or types of corruption. Moreover, the current Ukrainian criminal legislation lags behind in real life and needs further improvement. This provision fully applies to the rules governing criminal liability for specific types and forms of corruption.

Undoubtedly, the legal reason for the existence of corruption may be improper legal regulation of campaign financing in public authorities and local self-government, which generates electoral corruption, when financial donations for these purposes pass by the election funds of candidates for public office.

In addition, the election legislation itself is not without significant shortcomings that contribute to the manifestation of corruption, as it itself does not ensure the free expression of the will of voters and requires constant and consistent modernization.

Quite of ten in research as a legal factor contributing to the existence and reproduction of corruption crime, such a legal phenomenon, is mentioned as the presence of immunity from the criminal prosecution of certain political actors, both representatives of public authorities and local governments, and candidates for these positions.

According to them, any release from liability creates a violation of existing norms of conduct and methods of combating crime, which is expressed in the inevitability of the application of criminal law for each crime and to any individual, regardless of his official position. In addition, violation of the universally recognized principle of justice in the field of justice causes significant moral damage to society, as it affects the psyche of the citizen, distorts his legal awareness, causes disrespect for current legislation and management. Therefore, it is no coincidence that in modern society there is, strengthened and for a long time there is an opinion that any government (politics) "dirty business", and the law - "that draw".

Concluding the review of the legal causes and conditions of corruption, it should be noted that when reforming the civil service and creating an appropriate legal framework for its passage, it is necessary to take into account the best positive foreign experience and implement "codes of honor" or "codes of ethics" for civil servants. The main task should be not to draft new rules of conduct, which have already been enshrined in law more than once ("code of ethics", "code of conduct", "code of morality") and should be a benchmark for implementation not only by officials but also by any the average citizen, and the detailed development of mechanisms for their use. Only under the latter condition will codes of ethics and morals be able to become an effective means of preventing corruption and a condition for increasing trust in the authorities.

Among the main socio-economic factors that determine corruption in the context of public administration reform, experts attribute primarily the low salaries of public authorities and local governments, which today is not competitive. Modern domestic researchers [6] point 
to the low salary of public servants as corrupt, ie provokes corruption, and quite rightly assume that it (salary) should be more in the official than in the person whose issues he solves.

In the last ten years, domestic scientists in the field of public administration [6] have raised the question of the need for scientific development of remuneration for public servants of different categories depending on the complexity of work, employee skills, efficiency of his professional (official) activities. They point out that wages symbolize the evaluation of work in the field of management, which affects the prestige of the profession and the distribution of labor resources. In this case, it is fair to ask what salary requirements for public servants should apply at present.

Another socio-economic factor of the existence and reproduction of corruption is the lack of housing and other social benefits for public servants, i.e. their material, financial and other social insecurity on the part of the state and its bodies.

Reflecting on the organizational and managerial factors of corruption, it seems to us a vicious practice of holding public office by "political appointees", because the system of governing public authorities can move to amateurs, not to professionals. At the same time, there is no certainty that even a competent official from among the "political appointees", while serving in public authorities and local selfgovernment, will defend the interests of the state and society, and not the interests of the political organization or association represented by this person. (party, movement, bloc, faction, etc.). Because, according to the fair remark of scientists [9, p. 69], "... where" one's interests "begin, politics ends and corruption begins". In this situation, we see a special case of conflict of interest, ie there may be situations where personal (or party) interest may affect the objective performance of a representative of public authorities or local self-government.

According to domestic experts [9, p.105], among the organizational and managerial reasons for the existence of corruption in the context of continuous reform of public authorities and local government in modern society should include the instability of the civil service in these bodies. In support of this thesis, we can present several arguments that have already been expressed by domestic experts in the scientific literature.

First, it is difficult to disagree with the opinion of Bilynska L.V. [4, p.139], which indicates that "... the prevailing political instability in society forms a sense of insecurity among officials at various levels, the psychology of temporary rulers who come to power in order to make money, including using their official position, as well as the associated authority. "

Second, fears for their political future and present force senior officials or heads of local governments to select "their teams" in the administration, subordinate not on the basis of professionalism, but on other grounds: kinship, property, party or national affiliation and, of course, personal devotion. The principles of the Soviet civil service work here, in which citizens remain subordinate to officials, and they, in turn, are subordinate to their superiors, but not to the citizens who elected them. As a result, in fact, the norm of social governance in the regions of
Ukraine has become a corrupt principle of public service personal devotion.

In view of the above, it becomes clear why there are so many people among the ruling regional political elite who have previously compromised or discredited themselves with incompetent decisions, immoral wrongdoing, criminal prosecution for corruption and economic crimes, and outright scams. These individuals are often forgiven even for clearly criminal behavior for their loyalty to a regional leader or head of a local government. This provides a reliable "circular guarantee" and concealment of "dishonest misconduct" of each member of this "team" and forms an informational secrecy of officials from most members of society.

Most often in the modern scientific and educational literature on the problems of combating corruption, regardless of the vector of its focus, type and scope, there is such an organizational and managerial reason as low efficiency of state law enforcement and regulatory agencies to combat corruption.

In our opinion, the inefficiency of law enforcement agencies in stopping and preventing corruption is caused by the "leaching" in the last decade of experienced and honest personnel from the law enforcement system. All this ultimately leads to greater public danger and the prevalence of both the very manifestations of corruption and its negative social consequences.

Another organizational and managerial reason that maintains the negative trends of corruption in society, derived from the previous one, is the inadequate coordination of law enforcement agencies both within the state (at the interdepartmental and interregional level) and at the international level.

Ideological factors are important factors in determining corruption. Among the ideological factors that determine corruption are some well-known political phenomena and processes.

In our opinion, the factors that naturally give rise to corruption are unprepared, and sometimes simply unsystematic (chaotic), fleeting "campaigns" or "crusades" to combat corruption in all its forms, types, areas and manifestations. Such "campaigns" do more harm to this struggle than positive effect. Because these widely advertised anti-corruption "campaigns" in the media often pursue political goals and are one of the immoral ways to achieve them.

Such "campaigns" in the fight against crime, including corruption, are rightly considered in the modern domestic scientific literature as political speculation on the problem of crime.

As modern political reality shows, senior government officials or candidates for these positions loudly proclaim an uncompromising and uncompromising fight against corruption ("clean hands" or "zero tolerance for corruption" operations), do not always fulfill their commitments after how to achieve the set political goals related to the occupation or retention of the relevant public positions for themselves or their political supporters.

In such states and regions, according to Christian de Brie [5, p. 73], the illusion of a constant and growing fight against corruption at the governmental, law enforcement and judicial levels, both nationally and at a coordinated international level, is created. 
Another ideological factor of the existence of corruption may be the lack of political and legal culture of the majority of Ukrainians, which is reflected primarily in the process of elections to representative and legislative bodies of state and local government, when voters vote for people who offered small sums of money or material values, receiving insignificant property benefits, or believing in adventurous promises of rapid, within 3-5 years (and sometimes immediate, in the case of the election of a candidate for the relevant higher public office), a radical change in social life in the country or region for the better without any -what additional labor efforts of the voters themselves. Voters, as a result of their indifference, recklessness, security, or indifference to the future, allow themselves to be manipulated to achieve political goals, while forgetting that they will inevitably be responsible for their choices in the future.

Domestic voters have not yet learned to be strict about their choices, they do not know how to distinguish populist gossip from serious people. Too often they rush to new names precisely because they are new, and they choose leaders they didn't know about yesterday, and they don't know today.

Among the socio-psychological factors that determine corruption, in our opinion, should include, first of all, the existing socio-psychological environment in a number of public authorities and local governments, in which almost every employee is a salesman, where people who evade giving or receiving bribes, are considered "white crows" they are treated as "strangers" or eccentrics, in some cases by various available ways and means of persecuting them for such positive behavior.

Another socio-psychological factor of the existence of corruption is the perception of society, its political institutions and government agencies to "acquire" votes by providing inexpensive gifts, promises of quick material enrichment or a "bright future" by candidates for elected government and local government. as a normal political phenomenon. With all the evidence that such a phenomenon should be considered immoral, illegal or criminal activity of these policy actors or their representatives.

\section{CONCLUSIONS}

There are at least two reasons why the international community (or, to be more precise, the leadership of the strongest states) is concerned about the level of corruption in Ukraine. First, according to many foreign politicians and experts, corruption directly determines the quality of public administration in the country. But, as shown above, there is no direct link between the level of corruption and the effectiveness of democratic transit, at least in the situation with Ukraine. Secondly, a corrupt state poses a threat not only to itself and its own society, but also in the era of globalization - and to other countries because of the danger of illegal spread of "high technology", money laundering in international banks, etc., because the concept of "state security" increasingly departs only from the military component. If in the early to mid-1990s corruption was assessed by international analysts as a "disease of growth" in the context of democratic transit, as corruption was treated almost exclusively as a companion to authoritarianism, poverty and mismanagement in the country, then by the beginning of the XXI century estimates have faded considerably, and the discourse associated with this topic began to abound with the terms "risk", "danger", "need to put pressure".

Thus, the dominant strategies in influencing these international institutions to fight corruption are the following:

- conducting public opinion polls and political expertise;

- public disclosure of facts and participants in corrupt activities who will be prohibited from participating in bankfinanced projects;

- allocation of funds for reforms and individual activities in the recipient country (it is obvious that international institutions of influence allocate funds precisely and only for those projects that they deem necessary); this necessitates an independent audit of the funds provided;

- expansion of technical assistance to law enforcement agencies (it can be, for example, information).

It is determined that it is necessary to strengthen the institutions of civil society, the development of independent media, ensuring legal literacy. The targets are international anti-corruption institutions, the political establishment and emerging civil society in Ukraine.

\section{References:}

1. Andrushchenko, L.V. (2016), "The essence of the phenomenon of "corruption" and the reasons for its existence in Ukraine", Pravo i suspil'stvo, vol. 3(1), pp. 148-153.

2. Bachynska, I.S. (2017), "Determinants of corruption in Ukraine, or why civil servants are involved in the corruption process", Efektyvnist' derzhavnoho upravlinnya, vol. 32, pp. 377-382.

3. Bezzub, I. (2016), "Anti-corruption policy in Ukraine", Hromads'ka dumka, [Online], vol. 10 (92), available at: http://nbuviap.gov.ua:anti koruptsijnapolitika-v-ukrajini (Accessed 4 Aug 2020).

4. Bilynska, L.V. (2018), "Corruption as a social, psychological and moral phenomenon", Naukovyy visnyk Mizhnarodnoho humanitarnoho universytetu. Yurysprudentsiya, vol. 6-1 (1), pp. 138-141.

5. llyenok, T.V. (2015), "Fight against corruption: international experience", Yurydychna nauka, vol. 2, pp. $71-77$.

6. Kalnysh, Yu. G. (2019), "The concept of scientific support of state policy of Ukraine in the field of anticorruption", [Online], Natsional'nyy instytut stratehichnykh doslidzhen', available at: http://www.niss.gov.ua/ Monitor/february2019/7 (Accessed 14 Aug 2020).

7. Kozak, L.S. and Fedoruk, O.V. (2016), "Formation in society of the idea of intolerance to manifestations of corruption as a basic component of the mechanism of realization of anti-corruption strategy in Ukraine", Ekonomika ta upravlinnya na transporti, vol. 3, pp. 15-31.

8. Mykhnenka, A. M. (2012), Zapobihannya ta protydiya koruptsiyi [Prevention and counteraction to corruption], Vyd-vo NADU, Kyiv, Ukraine.

9. Revak, I.O. ( 2011), Koruptsiya: teoretyko-metodolohichni zasady doslidzhennya [Corruption: theoretical and methodological principles of research] / [author. col: I.O. Revak and others], Lviv State University of Internal Affairs, Lviv, Ukraine.

Стаття надійшла до редакчї 14.08.2020 p. 